AperTO - Archivio Istituzionale Open Access dell'Università di Torino

\title{
Sonic hedgehog patterning during cerebellar development
}

\section{This is a pre print version of the following article:}

Original Citation:

Availability:

This version is available http://hdl.handle.net/2318/1571712

since 2016-06-24T10:16:06Z

Published version:

DOI:10.1007/s00018-015-2065-1

Terms of use:

Open Access

Anyone can freely access the full text of works made available as "Open Access". Works made available under a Creative Commons license can be used according to the terms and conditions of said license. Use of all other works requires consent of the right holder (author or publisher) if not exempted from copyright protection by the applicable law. 


\section{Cellular and Molecular Life Sciences \\ Sonic Hedgehog patterning during cerebellar development. --Manuscript Draft--}

\section{Manuscript Number:}

Full Title:

Article Type:

Corresponding Author:

Corresponding Author Secondary Information:

Corresponding Author's Institution:

Corresponding Author's Secondary Institution:

First Author:

First Author Secondary Information:

\begin{tabular}{|l|}
\hline Order of Authors: \\
\hline Order of Authors Secondary Information: \\
\hline Funding Information: \\
\hline Abstract: \\
\hline
\end{tabular}

\section{Suggested Reviewers:}

Opposed Reviewers:
Sonic Hedgehog patterning during cerebellar development.

Unsolicited review

Ketty Leto

University of Turin

Turin, ITALY

University of Turin

Annarita De Luca

Annarita De Luca

Valentina Cerrato

Elisa Fucà

Elena Parmigiani

Annalisa Buffo

Ketty Leto

\begin{tabular}{|l|l|}
\hline University of Turin & Dr Ketty Leto \\
\hline $\begin{array}{l}\text { Research Fund for the Promotion of Basic } \\
\text { Research } \\
\text { (RBFR10A01S) }\end{array}$ & Dr Ketty Leto \\
\hline
\end{tabular}

Robust evidence in literature indicates that the morphogenic factor Sonic Hedgehog (Shh) actively orchestrates several aspects of cerebellar development and maturation. During embryogenesis Shh signalling is active in the ventricular germinal zone (VZ) and represents an essential signal for proliferation of VZ-derived progenitors. Later, Purkinje cell (PC)-secreted Shh sustains the amplification of neurogenic niches active during postnatal development: the external granular layer $(E G L)$ and the prospective white matter (PWM) where excitatory granule cells and inhibitory interneurons, respectively, are produced. In addition, Shh signalling acts on Bergmann glia differentiation and during development sustains cerebellar foliation. Here we review the most relevant functions of Shh during cerebellar ontogenesis, underlying the role of this ligand in the development of different cerebellar phenotypes.

karl schilling

karl.schilling@uni-bonn.de

chin chiang

chin.chiang@vanderbilt.edu

isabelle dusart

isabelle.dusart@snv.jussieu.fr 


\title{
Sonic Hedgehog patterning during cerebellar development
}

Annarita De Luca $^{1,2}$, Valentina Cerrato ${ }^{1,2}$, Elisa Fucà ${ }^{1,2}$, Elena Parmigiani ${ }^{1,2}$, Annalisa Buffo ${ }^{1,2}$ \& Ketty Leto ${ }^{1,2 *}$

1Department of Neuroscience Rita Levi-Montalcini, University of Turin, I-10126 Turin, Italy, 2Neuroscience Institute Cavalieri Ottolenghi, I-10043 Orbassano, Turin, Italy,

* Corresponding author: Ketty Leto, Department of Neuroscience Rita Levi-Montalcini, University of Turin, Neuroscience Institute Cavalieri Ottolenghi, Regione Gonzole 10, I-10043 Orbassano, Turin, Italy. E-mail: ketty.leto@unito.it.

Keywords: Shh, mitogen, differentiation, cerebellum.

\section{Authors declare no conflict of interest.}

\begin{abstract}
Robust evidence in literature indicates that the morphogenic factor Sonic Hedgehog (Shh) actively orchestrates several aspects of cerebellar development and maturation. During embryogenesis Shh signalling is active in the ventricular germinal zone (VZ) and represents an essential signal for proliferation of VZ-derived progenitors. Later, Purkinje cell (PC)-secreted Shh sustains the amplification of neurogenic niches active during postnatal development: the external granular layer (EGL) and the prospective white matter (PWM) where excitatory granule cells and inhibitory interneurons, respectively, are produced. In addition, Shh signalling acts on Bergmann glia differentiation and during development sustains cerebellar foliation. Here we review the most relevant functions of Shh during cerebellar ontogenesis, underlying the role of this ligand in the development of different cerebellar phenotypes.
\end{abstract}

\section{Introduction: the Hedgehog Pathway}

Sonic Hedgehog (Shh) signalling is implicated in the regulation of key events during mammalian developmental processes [1]. The first gene of the Hedgehog family (Hh) was cloned in Drosophila in the early 1990s [2], and its role in controlling the proper segmental identity during fruit fly embryonic development has been identified [3, 4]. Shortly after, different Hh genes in Vertebrates were described $[5,6]$ and explained as a result of genome duplication. They are classified as Desert Hedgehog (Dhh), Indian Hedgehog (Ihh) and Shh [7]. In mammals, Shh is expressed starting from early embryogenesis and is one of the molecules responsible for the regulation of central nervous system (CNS) patterning [8]. Successively, during organogenesis, Shh is broadly detected in many tissues where it plays key roles as morphogen, mitogen and guidance molecule. Given its prominent role during development, alteration of its physiological functions are implicated in many human pathologies [9-11]. 
The spatial and temporal Shh expression pattern results from the combined action of multiple enhancer elements present in its extensive regulatory domain, controlling Shh transcription in different tissues [12-16]. However, only recently specific transcription factors have been discovered to directly control Shh enhancer activity. After transcription, Shh becomes an active ligand through evolutionarily conserved multistep processes [17-22] (Fig. 1 $\mathrm{A}_{1}$ ). Initially, it is synthesized as a 45$\mathrm{kDa}$ precursor and then it is auto-proteolytically cleaved by its own C-terminal domain into two secreted peptides: a 19-kDa amino terminus (Shh-N) with a signalling domain and a 26-kDa carboxy terminus (Shh-C), devoid of any signal transduction activity [23, 24] (Fig. 1 $\mathrm{A}_{1}$ ). During auto-proteolysis, a cholesterol moiety is added to the C-terminus of Shh-N to anchor it to the plasma membrane, resulting in concentration in the lipid membrane rafts that facilitates interaction of low levels of Shh-N protein with its receptor [25-27, 18, 23]. Moreover, the cholesterol modification is also essential for a second lipophilic addition, a palmitoyl insertion at $\mathrm{N}$-terminus of Shh-N [27, 18, 23] (Fig. 1 $\mathrm{A}_{1}$ ). The presence of this second lipid incorporation is indispensable for Shh-N to multimerize and sequester the lipid anchor within the multimer, resulting in the detachment from the plasma membrane (Fig. $1 \mathrm{~A}_{1}$ ). This soluble form of Shh-N is now able to diffuse far from its site of synthesis, resulting in a broad and long-distance effect [28-31]. The secretion of soluble multimer Shh-N can also be controlled by Dispached1 transmembrane protein (Disp1), containing a sterol sensing domain (SSD) able to displace Shh-N oligomers from lipid rafts [32, 33] (Fig. 1 $\left.\mathrm{A}_{1}\right)$.

Before reaching the surface of responding cells, Shh-N moves between many cells probably under the regulation of multiple molecules and mechanisms, like megalin [34] and glypicans [35] (Fig. $1 \mathrm{~A}_{2}$ ). Megalin is an endocytic receptor belonging to the low density lipoprotein receptor family, and mediates cell endocytosis of N-Shh, targeting it for lysosomal degradation or transcytosis [34]. The affinity of N-Shh for megalin is augmented when the ligand is sequestered near the cell surface by glypicans, which are heparan sulfate proteoglycans [36] (Fig. 1 $\mathrm{A}_{2}$ ). Lysosomal degradation is implicated in the extracellular regulation of $\mathrm{N}-\mathrm{Shh}$ concentration, whereas megalin-mediated transcytosis may facilitate long range signaling of N-Shh during early development, across neural tube epithelial cells [34, 37].

In vertebrates, the receptor and co-receptors of $\mathrm{N}$-Shh are concentrated in the primary cilium, a microtubule-based membrane protrusion [38]. Emerging evidence suggests that the cell surface machinery responsive to Shh comprise is a complex interaction network [39]. Indeed, the binding of Shh-N to its specific receptor Patched 1 (Ptch1), a 12-pass transmembrane protein, is facilitated by other transmembrane proteins, like Cdo, Boc and Growth Arrest Specific 1 (Gas1; Fig. 1B 1-3 $_{\text {; }}$ [40, 
41]). These co-receptors regulate Shh signalling by binding to Shh in synergic interaction with Ptch1. They are down-regulated in response to Shh signalling in a negative feedback [42-45]. This feedback simultaneously up-regulates Ptch1 and other two additional cell surface Shh-binding proteins, hedgehog interacting protein 1 (Hhip1; [46]), a membrane-anchored glycoprotein, and patched 2 (Ptch2), a structural homolog of Ptch1 that arose from a gene duplication event [47]. Ptch2 and Hhip1 binding to Shh-N ligand compete with active ligand-receptor interactions to alter the balance between bound and unbound Ptch1, resulting in cell autonomous modulation of cell signaling activity. Furthermore, the resulting transcription of Ptchl gene in response to Shh signalling activation leads to an auto-inhibition process where produced Shh-N is no longer sufficient to block all the available Ptch1 [40].

In absence of ligand, Ptch1 catalytically inhibits the activity of the Shh signal transducer Smoothened (Smo), a seven-transmembrane-span receptor like protein [48], modulating the concentration of its small agonist or antagonist molecules, such as Oxysterols [49], vitamin D3 derivatives [50, 48, 51-53], cyclopamine and jervine [51] (Fig. 1B 1 ). Ptch1, which is structurally related to transporter and pump protein, may send endogenous sterols away from Smo, inhibiting its action [54]. After Shh interaction with Ptch1, sterols can bind to Smo and its inhibition is released [49] (Fig. 1 $\left.\mathrm{B}_{2}\right)$. Thus, the seven-transmembrane receptor shuttles from an endocytic vesicle to the cilium, while the hedgehog patched complex is internalized and degraded by lysosomes [55] (Fig. $1 B_{2}$ ). To activate Smo a Shh-induced Smo conformational switch is required. In particular, in mice Shh-N can regulate the accessibility of Smo to CK1 1 and GRK2 kinases, which bind and phosphorylate the Smo C-tail in a dose-dependent manner, shifting the closed conformation of Smo in an open shape [56] (Fig. 1B 3 ). Phosphorilated Smo activates intracellular signals regulating several protein kinases, which activate a class of transcription factors known as glioblastoma (Gli) proteins, homologs of cubitus interruptus (Ci) proteins in Drosophila [57]. The regulation of Gli proteins activities is similar to $\mathrm{Ci}$, although in mammals three Gli proteins have been discovered (Gli1-3; [58, 59]). In the absence of Shh stimulation, the nuclear localization of Gli2 and Gli3 proteins is inhibited by the binding in the cytoplasm of the Suppressor of Fused (Sufu), which is the major negative regulator of Shh signaling in mammals (Fig. 1B ; $_{1}$ [60-63]). In addition, Kif7 is also present in this complex acting as a scaffolding protein for PKA, GSK3 and CK1 kinases, responsible of Gli phosphorylation (Fig. 1B I $_{1}$. After phosphorylation, GLI2 is rapidly degraded, whereas Gli3 is cleaved and the partial Gli3 acts as a repressor, blocking transcription of downstream targets [64-66, 29, 67]. On the other hand, Gli1 transcription has been demonstrated to increase in response of Shh, and its level is a widely used biomarker for activated Shh signaling. Therefore, it is implied that Gli1 is not one of the initial transducer of the Shh signal [19]. In the 
presence of Hedgehog signaling, Smo induces the inhibition of Gli phosphorylation by dissociating the Sufu-Gli-kinase complex with consequent stabilization and nuclear accumulation of Gli family members (Fig. 1B 3 ; [67, 68]). In the nucleus of responding cells all Gli transcriptional factors, possessing highly similar zinc finger DNA binding domains, can bind the same DNA motif. However, Gli1 and Gli2 mainly function as transcriptional activators, while Gli3 is a transcriptional repressor (Fig. $1 \mathrm{~B}_{1,3} ;[69,70]$ ), suggesting that they might act on different target genes.

\section{Distinct functions of Shh during cerebellar development}

The secreted signaling molecule Shh plays critical roles in pattern formation of the vertebrate CNS. During neurulation, Shh is produced by the ventral midline mesoderm as well as by the ventral neural tube, and its activity is required for the determination of ventral characteristics along the anterior-posterior neuraxis [71]. At successive stages of development Shh signalling sustains the proper formation of several CNS regions, including the cerebellum. Here, Shh critically influences the initial phases of territorial determination and regulates the following steps of cerebellar progenitor maturation in primary and secondary germinal zones.

\subsection{Cerebellar territory and germinal zones}

The cerebellum arises from a specialized area at the midbrain/hindbrain boundary [72-74], where, at embryonic day 8.5 (E8.5), the interaction between homeobox genes Otx2 and Gbx2 defines the Isthmic Organizer region (IO; [75, 76]). The IO orchestrates the development of cerebellar and mesencephalic structures through the morphogenic activity of secreted factors, Fgf8 and Wnt1 [7779]. In the midbrain and cerebellum, Shh expressed in the ventral midline regulates dorsoventral pattering and expression of the midbrain-hindbrain organizer Fgf8 during early embryogenesis (from E8.5 to E12; $[14,80]$ ). It has been shown that retrovirus-mediated misexpression of Shh in the early chick neural tube disrupts midbrain-hindbrain boundary formation, causing the fusion of the two lateral cerebella primordia [71].

After territorial specification, cerebellar histogenesis starts at E9 in the mouse. At this age the cerebellar anlage is formed by two separated and symmetric bulges that during the following days grow and fuse together, giving rise to the unitary cerebellar plate, comprising the vermis and the two hemispheres [81]. Such developmental phase is also characterized by the formation of two germinative compartments just above the opening of the fourth ventricle: the rhombic lip (RL), located at the outer aspect of the cerebellar plate, adjacent to the roof-plate, and the ventricular zone (VZ), placed in the inner side, covering the fourth ventricle. These germinative districts are defined by the region-specific expression of two basic helix-loop-helix transcription factors: the pancreas transcription factor 1-a (Ptf1-a), expressed in the VZ [82], and the mouse homolog of Drosophila atonal (Atoh-1), present in the RL [83]. This spatially-restricted expression pattern defines the 
neurochemical compartmentalization of cerebellar precursors, as all GABAergic neurons (Purkinje cells, PCs, nucleo-olivary projection neurons of deep cerebellar nuclei, DCN, and all inhibitory interneurons - basket, stellate, Golgi and Lugaro cells) originate from Ptf1- $\mathrm{a}^{+}$precursors [82, 84, 85], while glutamatergic lineages (large projection neurons of DCN, unipolar brush cells, UBCs, and granule cells) derive from Atoh- $1^{+}$progenitors [85-91]. Recent experiments have shown that these transcription factors specify cerebellar progenitors within the two spatially segregated neuropithelial domains so to assure the appropriate production of GABAergic and glutamatergic neurons [85]. In particular, by means of knock-in mouse lines and by in utero electroporation Ptf1-a and Atoh-1 were ectopically expressed in the RL and in the VZ, respectively. Results were clearcut, showing that ectopically Ptf1-a-expressing RL cells produced GABAergic phenotypes, whereas ectopically Atoh- $1^{+}$VZ progenitors differentiate into glutamatergic populations [85]. The two primary germinative epithelia disappear at birth. Dividing VZ precursors emigrate into the cerebellar prospective white matter (PWM), whereas those of the RL move along the pial cerebellar surface, where they form the external granular layer (EGL). Postnatal neurogenesis is active in secondary PWM and EGL epithelia up to the third postnatal week to generate appropriate numbers of GABAergic and glutamatergic interneurons, respectively [81, 92].

The temporal schedule of generation of cerebellar phenotypes is also finely defined. Birthdating studies showed that projection neurons are produced first, at the onset of cerebellar neurogenesis, while both inhibitory and excitatory interneurons are generated later, during late embryonic and first postnatal life $[93,81,94]$.

It is well established that Shh actively regulates the amplification of cerebellar progenitors in both embryonic and postnatal germinal zones. This morphogen, secreted by Purkinje cells from E17.5 [95-97] and by choroid plexi at earlier time points [98], controls the production of appropriate numbers of excitatory and inhibitory interneurons (Fig. 2). In addition, it modulates the correct generation and development of glial progenitors and it exerts specific functions in different phases of granule cell development, in both normal and pathological conditions, such as medulloblastoma. Finally, Shh actively orchestrates the major dynamics of cerebellar foliation, sustaining normal processes of cerebellar growth and maturation.

\subsection{Shh and granule cells}

Granule neurons (GNs) represent the most abundant cell type in the brain (about $10^{8}$ granule cells in the adult cerebellum; $[93,99]$. These cells derive from Atoh- $1^{+}$progenitors migrating from the RL to the EGL. The entire process of granule cell production lasts from E12.5 to P14 and it is fundamental for the acquisition of regular cerebellar size and foliation [81]. Indeed it has been 
observed that reduction in GN number leads to the formation of smaller cerebella [100-102] and abnormal foliation, such as the persistence of just the five cerebellar cardinal lobules at P14 in rats $[103,104]$. In addition, abnormal proliferation of granule cell precursors (GCPs) is at the basis of pathological conditions such as medulloblastoma, the most common form of children malignant brain tumour (for review see $[105,106])$.

Numerous studies have analysed the mechanisms underlying the initial phases of GCP proliferation and migration from the EGL mitogenic niche [97, 107, 108]. In particular, it has been demonstrated that these steps are actively controlled by mitogenic factors secreted by PCs. Indeed, the relative number of granule cells is reduced in animal models characterized by a primary PC degeneration [109-111], whereas if the loss of PCs occurs later in postnatal period (as in the $p c d$ mutant mouse) the granule cell layer appears near normal [112, 111]. Shh produced by PCs is the most efficacious mitogen acting on granule cell development. Treatment of GCPs with Shh prevents the differentiation and induces a long-lasting proliferative response, while an inhibition of Shh signal dramatically reduces the mitotic activity of these precursors [97, 95, 113-115]. The pathway activated by this molecule involves the upregulation of the target genes Patched, Gli1 and Gli2, which are dynamically expressed during development by proliferating precursors [113, 116, 104]. For example, the activation of Gli2-mediated pathway is important to ensure the correct extension of GCPs in the EGL and the consequent normal patterning of cortical folia [104]. Other important mediators of Shh-induced proliferation are N-myc, cyclin D1 and cyclin D2, that directly promote the entry of precursors into cell-cycle and DNA replication [116-118]. Overexpression of these molecules is sufficient to boost GCP proliferation, but the amplitude of the response is strictly dependent on the particular molecule involved [116].

Shh protein is present in PC dendrites and axons during embryonic and postnatal development, and persists in the adult, suggesting multiple roles played in the developing and mature circuitry [97]. However, the decreased expression of Gli1 in the innermost part of the EGL indicates that the response to the Shh signal is progressively switched off in granule neurons [107, 104]. Cells in the deepest part of EGL, as well as in the ML and in the internal granular layer (IGL), do not express cyclin-D1, indicating their status of non-proliferating cells [119-121]. Thus, at the time when they are ready to leave the proliferative niche, GCPs undergo some cell-autonomous changes that are critical to exit the cell cycle. In addition, these cells start the expression of cyclin-dependent kinase inhibitors, such as $\mathrm{p} 27$. This molecule arrests their proliferation and induces the differentiation programme both in vitro and in vivo [122, 123]. However, in the p27 knockout mice GCPs are still able to leave the cell-cycle and differentiate into mature granule cells, indicating that p27 is not the unique factor responsible for this mechanism [108]. It has been suggested that extracellular matrix 
(ECM) glycoproteins, such as laminin and vitronectin, can modulate GPC responses to Shh [124].

GCPs actively proliferate in the presence of Shh when cultured on laminin, which is present in vivo in the outer EGL, but not on vitronectin, which is normally contacted by granule cells in the deepest EGL and IGL $[96,124]$. Therefore, the same molecular elements may regulate both proliferation and differentiation signalling of GCPs, depending on the pattern of ECM molecules and receptors expressed in different parts of the EGL.

\subsection{Shh and GABAergic interneurons}

GABAergic interneurons comprise multiple subsets of morphologically and neurochemically distinct phenotypes integrated at different levels of the cerebellar cortex and DCN. These cells are produced from late embryonic life to the second postnatal week; the peak is around P5 and the production of $75 \%$ of all inhibitory interneurons occurs prior to P7 [125]. Maricich and Herrup [126] identified the progenitors of inhibitory interneurons as a population of $\mathrm{Pax}-2^{+}$cells, which appear in the $\mathrm{VZ}$ around $\mathrm{E} 12$ and later emigrate into the cerebellar parenchyma. Inhibitory interneuron precursors continue to proliferate during their migration in the PWM [127-129, 125] and they generate interneuron phenotypes according to an inside-out progression. DCN interneurons are the first to be born during embryonic and early postnatal life, followed by granular layer (GL) interneurons (Golgi and Lugaro cells) and, finally, by ML ones (basket and stellate cells; $[126,128,125,130]$. Interestingly, transplantation experiments have demonstrated that all these different interneuron subsets derive from a single population of $\mathrm{Pax}-2^{+}$immature interneurons that acquire mature phenotypic traits under the influence of local instructive cues provided by the PWM microenvironment $[128,129]$.

The cellular composition of the PWM is complex, including cells with neural stem cell (NSC)-like properties [131, 132], dividing progenitors and astrocytes, interneurons and oligodendrocytes at different maturation stages [127, 133, 134, 129, 135, 136, 121].

It has been shown that proliferative intermediate progenitors of GABAergic interneurons in the PWM are Ptf1-a ${ }^{+}$cells that start the expression of Pax-2 during their last S phase $[126,129,136]$.

Recent findings suggest possible lineage relationships between $\mathrm{Ptf}_{1} \mathrm{a}^{+}$intermediate progenitors of GABAergic interneurons and Tnc ${ }^{\text {low }} \mathrm{CD} 15^{+}$astrocyte precursors [136]. Both populations derive from a population of $\mathrm{Tnc}^{\text {low }}$ and $\mathrm{CD}_{133^{+}}$neural stem-cell-like primary progenitors of the PWM, whose production is critically maintained by PC-delivered Shh [136]. Indeed, blockade of Shh signalling in Tnc-expressing cells disrupts the PWM niche, decreasing the numbers of intermediate progenitors of both interneurons and astrocytes, causing also a dramatic reduction of their mature phenotypes [136]. Notably, such specific effect of Shh is independent of the classical role of this 
mitogen in regulating GCP proliferation [97], as direct perturbation of GCP expansion does not alter GABAergic progenitor production [136].

Another proof of a direct effect of Shh on inhibitory interneuron production has been also provided by recent in vitro data: the exogenous administration of the recombinant amino-terminal active fragment of Shh (Shh-N) on cerebellar slices obtained by PWM regions of P2 mice showed an enhanced amplification of Pax- $2^{+}$cells [137]. This effect was significant both at 1 and 2 days in vitro, whereas it did not occur in presence of the Shh-antagonist cyclopamine [137]. In addition, Shh mitogenic effect on newborn Pax $-2^{+}$cells disappears at late postnatal stages as P7, when the bulk of GABAergic interneurons have been already produced [125, 138]. Gene expression analysis of sorted $\mathrm{GFP}^{+}$cells from Pax-2-GFP transgenic mice revealed that Shh pathway is active in immature Pax $-2^{+}$interneurons, which express both the Shh receptor Ptch1 and the Shh target gene Gli1 [137]. Similar results were confirmed by in situ hybridization: Gli1 and Ptch1 mRNAs were detected in P2 cerebella in the EGL, PCL and PWM, in line with former studies [113, 126, 96, 136]. Moreover, double Gli1 ${ }^{+} / \mathrm{Pax}-2 \mathrm{GFP}^{+}$and $\mathrm{Ptch} 1^{+} / \mathrm{Pax}-2 \mathrm{GFP}^{+}$interneurons were found, confirming the presence of an active Shh signals in $\mathrm{Pax}-2^{+}$cells [137], although its role during successive interneuron maturation remain to be clarified.

At earlier developmental stage (E16) the Gli1 mRNA was already present in the cerebellum, though less expressed compared with postnatal ages. Both $\mathrm{Gli1}^{+}$cells and double positive Gli1/Pax-2GFP cells were present in the VZ/SVZ region, or scattered in the cerebellar parenchyma, showing that during embryonic development Shh pathway is already active in Pax $-2^{+}$cells located in germinal and migratory sites [137]. Exogenous administration of Shh-N on embryonic cerebellar explants increased the fraction of proliferative cells becoming Pax $-2^{+}$interneurons but only at the end of the culture period, suggesting that different dynamics might regulate the production of GABAergic interneurons at embryonic and postnatal developmental stages [137]. This possibility is also supported by previous in vivo data showing that Shh signalling is active in the cerebellar VZ and essential to regulate the proliferation of radial glia and, consequently, the expansion of GABAergic interneurons [98]. In this case, however, endogenous PCs are not the source of Shh ligand, which is secreted by the choroid plexi and transventricularly delivered by the embryonic cerebrospinal fluid [98].

Overall these recent studies highlight the fundamental role of Shh in regulating interneuron numbers by maintaining the embryonic and postnatal niches in which these cells are produced.

\subsection{Shh and cerebellar glia}

Cerebellar astrocytes and oligodendrocytes comprise morphologically distinct cell types located at different sites in the cerebellar cortex and white matter [139-141]. 
Several evidence indicated that astrocytes (comprising Bergman Glia-BG- cells and parenchymal astrocytes) derive from the VZ [139, 142-144, 130], whereas oligodendrocyte precursors (OPCs) seem to mainly originate from exogenous sources and, at later embryonic stages, populate the cerebellar parenchyma and continue to amplify [145, 146, 134].

Some studies investigated the role of the Shh signaling pathway on both astrocytes [147-149] and oligodendrocytes [150-156] in developing and mature brain and spinal cord. In the cerebellum Shh has been described to play a direct role on both BG cells and oligodendrocytes, regulating their differentiation and proliferation, respectively. Moreover, this ligand critically maintains the VZ and PWM niches, controlling the proliferation of, respectively, radial glia cells and intermediate progenitors of parenchymal astrocytes ([98, 136]; see previous paragraph). Beside that, it is not clear whether Shh could exert some roles on mature parenchymal astrocytes.

Before Shh was shown to directly affect the BG population, Traifford et al. [157] and Wallace [113] had already observed high expression levels of Ptch and Gli1 in small cells in the PCL, presumably in BGs, suggesting that Shh signaling pathway was active in these cells. Confirmation of a direct action of Shh came shortly later, when Dahmane and Ruiz-I-Altaba [95] first demonstrated the role of this ligand in BG differentiation, but, intriguingly, not in BG progenitor proliferation [95]. These results were in accordance with previous data revealing the key role of PCs in the control of BG maturation [158, 79]. Yet, BG persist in both Gli2 mutant embryos [96] and Gli2-En1 conditional knock-out mutants, in which Gli2 deletion is restricted to cerebellar precursors [104], thus demonstrating that Shh signaling through Gli2 is dispensable for BG specification. However, the latter mutant model showed an abnormal glial morphology, characterized by the disorganization and deformity of the glial fibers. This phenotype was explained as a secondary effect of the abnormal PC morphology [104]. Similarly, Lewis et al. [97], through transgenic mice models specifically developed to prevent Shh production by PCs at different ages, observed alterations in BG only after P5, while BG morphology was normal at previous developmental stages. Also in this case the results were interpreted as a secondary effect of PC disorganization and absence of granules' parallel fibers and not as a direct consequence of Shh absence on BG differentiation. In contrast, Mecklenburg et al. [159] proposed a direct role of Shh in the regulation of BG maturation, suggesting that the altered glial morphology observed in conditional Shh mutants [97] was not subordinate to defective PCs. Indeed, Gdf10, a member of the transforming growth factor beta (TGF-ß)-superfamily strongly expressed in cerebellar BG cells from E15 (i.e. from the moment they are specified) and, thus, potentially correlated to BG specification from radial glia, was shown to be intensely reduced in conditional Shh cerebellar mutants. The rapid down-regulation of this 
glial-specific gene in absence of Shh could suggests a direct role of this ligand in BG specification, despite the exact mechanisms still need to be clarified.

Shh was also shown to affect the proliferation of cerebellar oligodendrocytes, the glial component responsible for the myelin synthesis. Bouslama-Oueghlani et al. [160] used cerebellar organotypic cultures to investigate the influence of PCs (i.e. the only type of cerebellar neuron to be myelinated) on the timing of oligodendrocyte differentiation. In particular, using cerebellar slices cultures in which the number of PCs was significantly different, authors found that soluble factors produced by PCs were able to affect OPC population. Among these factors Shh was shown to be downregulated during PC postnatal maturation, whereas vitronectin resulted upregulated. Importantly, Shh and vitronectin administrated to postnatal organotypic slices had opposite effects on OPCs, stimulating their proliferation and differentiation, respectively [160]. These effects were reverted by Shh and vitronectin- antagonists. On the whole, these results highlight that both neuronal and glial development are highly synchronized in the cerebellum [160], as well as in other CNS regions [161-163].

\subsection{Shh orchestrates normal cerebellar foliation}

A prominent feature of cerebellar morphology is its folded appearance, whereby fissures separate its anterior-posterior extent by lobules [164]. By E18.5 four principal fissures are evident in midsagittal sections of the mouse vermis, leading to distinguish five cardinal lobes (anterobasal, anterodorsal, central, posterior and inferior lobes; [164]). Afterwards, additional (non principal) fissures divide the cardinal lobes into lobules, reaching the total of ten lobules identifiable in the adult murine cerebellum [164].

The mitogenic action of Shh on GPCs is the driving force for the initial formation of fissures [164], thereby affecting also cerebellar foliation process, which is the process leading to the morphologically unique brain structure of folia separated by fissures [96, 104]. In particular, it has been shown that Shh signaling spatially and temporally correlates with fissure formation and that Gli2 is the principal activator of Shh-induced GCP proliferation [96]. Indeed, Gli2-null mutants showed decreased foliation at birth and reduced numbers of GCPs, whereas Shh overexpression in wild-type cerebella leaded to normal cerebellar foliation but also to an increased cerebellar size, as consequence of prolonged GCP proliferation [96]. Other experiments clarified that the level of Shh signaling regulates the extent and complexity of cerebellar foliation, but non its typical pattern [104]. Namely, in the absence of Gli2 foliation proceeds but the process of lobulation is delayed and prematurely arrested; further reduction in foliation occurs in double Gli2 and Gli1 null mutant mice, whereas when the entire Shh signaling is removed foliation is totally inhibited because of a rapid exhaustion of GCPs after E17.5 [104]. Collectively, these findings suggest that Shh is not 
necessary to initiate foliation and to determine the position of the fissures, but is more likely to be a regulator of the extent and complexity of foliation. This interpretation implies that at embryonic stages in the absence of Shh some GPCs are able to start mitosis, allowing the first indentations to form, and that at later stages before and after birth Shh becomes necessary to sustain the expansion of the EGL [97].

\section{Shh and cerebellar pathology: evidence from medulloblastoma}

Medulloblastoma (MB) is the most frequent form of primitive, neuroectodermal tumor during childhood, with estimated lethality of 30\% and high clinical heterogeneity. It is widely accepted that MB originates from GCPs and four different subtypes of MBs have been identified and classified according to their transcriptional profiles: I) WNT MBs; II) Shh MBs; III) Group C, frequently associated with TGF1 beta pathway abnormalities; IV) Group D, often related to tandem duplication of SNCAIP [165-169].

Shh-MBs represent one third of the total number of MBs [170, 171], both in childhood and adult age, even though it has been demonstrated that infant and adult MBs exhibit different transcriptional and genetic profiles. Northcott et al. [167] identified a number of homeobox family members as the mostly up-regulated genes in adult forms of Shh-MBs; infant MBs, instead, revealed high expression of transcriptional regulators functioning in brain development, such as ZIC2 and ZIC5. These dissimilarities lead to large variability in clinical and prognostic aspects of the disease through different ages: this is the reason why targeting of signalling molecules is a fundamental step to set up therapeutic approaches.

It has been demonstrated that Shh-MBs derive from aberrations in varied components of Shh pathway, such as Ptch1 [114, 172], Sufu [173, 174], Gli transcription factors [175] and Smo [176]. Studies on mice lacking Ptch function demonstrated that abnormal activation of Shh pathway through repression of its inhibitors leads to the formation of MBs [177, 178]. Similar mutations have been also described in patients with nevoid basal cell carcinoma syndrome - also known as Gorin syndrome - often associated with the formation of MB in childhood [179]. According to Kim et al. [180], Shh pathway alteration via Ptch in heterozygous mice induces a subset of GCPs to maintain their proliferative activity with consequent deregulation of developmental gene expression, rather than globally increase GCPs proliferation during postnatal development or interrupt programmed cell death. However, the complexity of the Shh pathway does not allow attributing MBs formation to abnormalities of just one element of the network, as demonstrated by the fact that only a percentage of Ptch mutant mice develop MB. Taylor et al. [173], in fact, identified Sufu as another tumor-suppressor gene in a subset of desmoplastic medulloblastomas whose mutation predisposes to MB by modulating the Shh signaling: they created a model in which 
Sufu cannot bind Gli transcription factors and allocate them from the nucleus, with consequent activation of SHH target genes. More recently, it has been also demonstrated that nevoid basal cell carcinoma syndrome, traditionally associated with Ptch mutations, could be caused by heterozygous loss-of-function germline mutations in Sufu. These studies contributed to the redefinition of the risk of MB in Gorlin syndrome on the basis of the related gene: in Ptch-related forms, the risk of MB has been reduced from $5 \%$ to $2 \%$ with a probability approximately $20 \mathrm{X}$ higher in Sufu-related forms [181, 182].

Other studies focused on the role of Gli1 expression in MB through the identification of the subset of Gli1 transforming target genes specifically expressed in MBs [183], or through the characterization of SHH signaling pathway members Gli-3 expression in relation with prognosis, suggesting that Gli1 or Gli2 expression in pediatric medulloblastoma might confer a worse outcome [184]. However, recently, new intriguing findings partly modified this classical view of Shhdependent proliferation of GCPs. Li et al. [185] disclosed a new population of progenitors cells in the EGL identified by the expression of the neural stem cells (NSC) marker Nestin. Surprisingly, Nestin $^{+}$cells do not express Math1 and are not responsive to Shh in vivo, even if they express the signaling-associated machinery. Nevertheless and though they account for only 3-5\% of EGL cells, they displayed enhanced tumorigenic potential and chromosomal aberrations following loss of the Shh receptor Ptch1 compared to Math ${ }^{+}$GCPs [185], raising important questions about the cellular origin of medulloblastoma [186].

\section{Concluding Remarks}

The role of Shh in the development of the CNS has been extensively investigated, leading to an indepth knowledge of extrinsic and intrinsic molecular machineries included in its signalling pathway. Moreover, beyond its role in ventral patterning, hedgehog signalling is now known to have multiple roles throughout development, favouring the processes of fate specification, oligodendrogenesis, stem cell maintenance and axon path finding. In the cerebellum, Shh pathway has been principally studied for many years in the contest of GCP proliferation. However (as described above), Shh ligand exerts additional roles on distinct cell populations, during the entire period of cerebellar development. In particular, Shh crucially sustains the expansion of neuronal and glial precursors within embryonic and postnatal niches, by means of different mechanisms, involving both cerebellar and extracerebellar strategies (Fig. 2). Moreover, Shh also induces BG maturation and oligodendrocyte amplification. As shown above, Shh signalling is a complex network involving different players that might modulate Shh function at different level, depending on the cell type. Intriguingly, the sole source of Shh during the late embryonic and postnatal development is PCs. These latter cells strategically orchestrate postnatal cerebellar morphogenesis 
through the modulated secretion of Shh and vitronectin. Despite the great amount of results in these areas, a deeper knowledge of the processes regulating the timing and balance of Shh/vitronectin production by Purkinje cells will certainly reveal more surprises about cerebellar developmental mechanisms.

\section{Acknowledgments}

We dedicate this work in memory of Prof. F. Rossi for his continuous support and encouragement. This work was supported by University of Turin and Research Fund for the Promotion of Basic Research Grant RBFR10A01S (K.L.). We thank Daniela Carulli for critical reading of this manuscript and helpful suggestions.

\section{References}

1. Simpson F, Kerr MC, Wicking C (2009) Trafficking, development and hedgehog. Mech Dev 126(5-6):279-288.

2. Tashiro S, Michiue T, Higashijima S, Zenno S, Ishimaru S, Takahashi F, Orihara M, Kojima T, Saigo K (1993) Structure and expression of hedgehog, a Drosophila segment-polarity gene required for cell-cell communication. Gene 124(2):183-189.

3. Nüsslein-Volhard C, Wieschaus E (1980) Mutations affecting segment number and polarity in Drosophila. Nature 287(5785):795-801.

4. Martinez-Arias A, Lawrence, PA (1985) Parasegments and compartments in the Drosophila embryo. Nature. 313(6004):639-642.

5. Wada H, Makabe K (2006) Genome duplications of early vertebrates as a possible chronicle of the evolutionary history of the neural crest. Int J Biol Sci 2(3):133-141.

6. Chang DT, Lopez A, von Kessler DP, Chiang C, Simandl BK, Zhao R, Seldin MF, Fallon JF, Beachy PA (1994) Products, genetic linkage and limb patterning activity of a murine hedgehog gene. Development 120(11):3339-3353.

7. Echelard Y, Epstein DJ, St-Jacques B, Shen L, Mohler J, McMahon JA, McMahon AP (1993) Sonic hedgehog, a member of a family of putative signaling molecules, is implicated in the regulation of CNS polarity. Cell 75(7):1417-1430.

8. Machold R, Fishell G (2002) Hedgehog patterns midbrain architecture. Trends Neurosci 25(1):10-11.

9. Bale AE (2002) Hedgehog signaling and human disease. Annu Rev Genomics Hum Genet 3:47-65.

10. Teglund, S, Toftgard R (2010) Hedgehog beyond medulloblastoma and basal cell carcinoma. Biochim Biophys Acta 1805(2):181-208.

11. Varjosalo M, Taipale J (2008) Hedgehog: functions and mechanisms. Genes Dev 22(18):2454-2472.

12. Jeong Y, El-Jaick K, Roessler E, Muenke M, Epstein DJ (2006) A functional screen for sonic hedgehog regulatory elements across a $1 \mathrm{Mb}$ interval identifies long-range ventral forebrain enhancers. Development 133(4):761-772.

13. Sagai T, Amano T, Tamura M, Mizushina Y, Sumiyama K, Shiroishi T (2009) A cluster of three long-range enhancers directs regional Shh expression in the epithelial linings. Development 136(10):1665-1674. 
4. Epstein DJ, McMahon AP, Joyner AL (1999) Regionalization of Sonic hedgehog transcription along the anteroposterior axis of the mouse central nervous system is regulated by Hnf3-dependent and -independent mechanisms. Development 126(2):281-292.

15. Tsukiji N, Amano T, Shiroishi T (2014) A novel regulatory element for Shh expression in the lung and gut of mouse embryos. Mech Dev 131:127-136.

16. Lettice LA, Heaney SJ, Purdie LA, Li L, de Beer P, Oostra BA, Goode D, Elgar G, Hill RE, de Graaff E (2003) A long-range Shh enhancer regulates expression in the developing limb and fin and is associated with preaxial polydactyly. Hum Mol Genet 12(14):1725-1735.

17. Amanai K, Jiang J (2001) Distinct roles of Central missing and Dispatched in sending the Hedgehog signal. Development 128(24):5119-5127.

18. Chamoun Z, Mann RK, Nellen D, von Kessler DP, Bellotto M, Beachy PA, Basler K (2001) Skinny hedgehog, an acyltransferase required for palmitoylation and activity of the hedgehog signal. Science 293(5537):2080-2084.

19. Ingham PW, McMahon AP (2001) Hedgehog signaling in animal development: paradigms and principles. Genes Dev 15(23):3059-3087.

20. Caspary T, Garcia-Garcia MJ, Huangfu D, Eggenschwiler JT, Wyler MR, Rakeman AS, Alcorn HL, Anderson KV (2002) Mouse Dispatched homolog1 is required for long-range, but not juxtacrine, Hh signaling. Curr Biol 12(18):1628-1632.

21. Dai P, Shinagawa T, Nomura T, Harada J, Kaul SC, Wadhwa R, Khan MM, Akimaru H, Sasaki H, Colmenares C (2002) Ski is involved in transcriptional regulation by the repressor and full-length forms of Gli3. Genes Dev 16(22):2843-2848.

22. Ma Y, Erkner A, Gong P, Yao S, Taipale J, Basler K, Beachy PA (2002) Hedgehogmediated patterning of the mammalian embryo requires transporter-like function of dispatched. Cell 111(1):63-75.

23. Porter JA, Young KE, Beachy PA (1996) Cholesterol modification of hedgehog signaling proteins in animal development. Science 274(5285):255-259.

24. Cohen MMJr (2004) The hedgehog signaling network. Am J Med Genet A. 123A(1):5-28. Erratum in: Am J Med Genet (2004) 124A(4):439-440.

25. Lee JJ, Ekker SC, von Kessler DP, Porter JA, Sun BI, Beachy PA (1994) Autoproteolysis in hedgehog protein biogenesis. Science 266(5190):1528-1537.

26. Porter JA, von Kessler DP, Ekker SC, Young KE, Lee JJ, Moses K, Beachy PA (1995) The product of hedgehog autoproteolytic cleavage active in local and long-range signalling. Nature 374(6520):363-366.

27. Pepinsky RB, Zeng C, Wen D, Rayhorn P, Baker DP, Williams KP, Bixler SA, Ambrose CM, Garber EA, Miatkowski K, et al. (1998) Identification of a palmitic acid-modified form of human Sonic hedgehog. J Biol Chem 273(22):14037-14045.

28. Lewis PM, Dunn MP, McMahon JA, Logan M, Martin JF, St-Jacques B, McMahon AP (2001) Cholesterol modification of sonic hedgehog is required for long-range signaling activity and effective modulation of signaling by Ptc1. Cell 105(5):599-612.

29. Wang Y, McMahon AP, Allen BL (2007) Shifting paradigms in Hedgehog signaling. Curr Opin Cell Biol 19(2):159-165.

30. Zeng X, Goetz JA, Suber LM, Scott WJJr, Schreiner CM, Robbins DJ (2001) A freely diffusible form of Sonic hedgehog mediates long-range signalling. Nature 411(6838):716720.

31. Chen MH, Li YJ, Kawakami T, Xu SM, Chuang PT (2004) Palmitoylation is required for the production of a soluble multimeric Hedgehog protein complex and long-range signaling in vertebrates. Genes Dev 18(6):641-659. 
32. Tian H, Tenzen T, McMahon AP (2004) Dose dependency of Disp1 and genetic interaction between Disp1 and other hedgehog signaling components in the mouse. Development 131(16):4021-33.

33. Burke R, Nellen D, Bellotto M, Hafen E, Senti KA, Dickson BJ, Basler K (1999) Dispatched, a novel sterol-sensing domain protein dedicated to the release of cholesterolmodified hedgehog from signaling cells. Cell 99(7):803-815.

34. McCarthy RA, Barth JL, Chintalapudi MR, Knaak C, Argraves WS (2002) Megalin functions as an endocytic sonic hedgehog receptor. J Biol Chem 277(28):25660-25667.

35. Fico A, Maina F, Dono R (2011) Fine-tuning of cell signaling by glypicans. Cell Mol Life Sci 68(6):923-929.

36. Gritli-Linde A, Lewis P, McMahon AP, Linde A (2001) The whereabouts of a morphogen: direct evidence for short- and graded long-range activity of hedgehog signaling peptides. Dev Biol 236(2):364-386.

37. Litingtung Y, Chiang C (2000) Control of Shh activity and signaling in the neural tube. Dev Dyn 219(2):143-154.

38. Goetz SC, Anderson KV (2010) The primary cilium: a signalling centre during vertebrate development. Nat Rev Genet 11(5):331-344.

39. Izzi L, Lévesque M, Morin S, Laniel D, Wilkes BC, Mille F, Krauss RS, McMahon AP, Allen BL, Charron F (2011) Boc and Gas1 each form distinct Shh receptor complexes with Ptch1 and are required for Shh-mediated cell proliferation. Dev Cell 20(6):788-801.

40. Marigo V, Davey RA, Zuo Y, Cunningham JM, Tabin CJ (1996) Biochemical evidence that patched is the Hedgehog receptor. Nature 384(6605):176-179.

41. Kang JS, Zhang W, Krauss RS (2007) Hedgehog signaling: cookinh with Gas1. Sci STKE 2007(403):pe50.

42. Hooper JE, Scott MP (2005) Communicating with Hedgehogs. Nat Rev Mol Cell Biol 6(4):306-317.

43. Tenzen T, Allen BL, Cole F, Kang JS, Krauss RS, McMahon AP (2006) The cell surface membrane proteins Cdo and Boc are components and targets of the Hedgehog signaling pathway and feedback network in mice. Dev Cell 10(5):647-656.

44. Zhang W, Kang JS, Cole F, Yi MJ, Krauss RS (2006) Cdo functions at multiple points in the Sonic Hedgehog pathway, and Cdo-deficient mice accurately model human holoprosencephaly. Dev Cell 10(5):657-665.

45. Lum L, Yao S, Mozer B, Rovescalli A, Von Kessler D, Nirenberg M, Beachy PA (2003) Identification of Hedgehog pathway components by RNAi in Drosophila cultured cells. Science 299(5615):2039-2045.

46. Chuang PT, McMahon AP (1999) Vertebrate Hedgehog signalling modulated by induction of a Hedgehog-binding protein. Nature 397(6720):617-621.

47. Motoyama J, Takabatake T, Takeshima K, Hui C (1998) Ptch2, a second mouse Patched gene is co-expressed with Sonic hedgehog. Nat Genet 18(2):104-106.

48. Taipale J, Cooper MK, Maiti T, Beachy PA (2002) Patched acts catalytically to suppress the activity of Smoothened. Nature 418(6900):892-897.

49. Corcoran RB, Scott MP (2006) Oxysterols stimulate Sonic hedgehog signal transduction and proliferation of medulloblastoma cells. Proc Natl Acad Sci U S A 103(22):8408-8413.

50. Bijlsma MF, Spek CA, Zivkovic D, van de Water S, Rezaee F, Peppelenbosch MP (2006). Repression of smoothened by patched-dependent (pro-)vitamin D3 secretion. PLoS Biol 4(8):e232.

51. Chen JK, Taipale J, Cooper MK, Beachy PA (2002a) Inhibition of Hedgehog signaling by direct binding of cyclopamine to Smoothened. Genes Dev 16(21):2743-2748. 
52. Chen JK, Taipale J, Young KE, Maiti T, Beachy PA (2002b) Small molecula modulation of Smoothened activity. Proc Natl Acad Sci U S A 99(22):14071-14076.

53. Frank-Kamenetsky M, Zhang XM, Bottega S, Guicherit O, Wichterle H, Dudek H, Bumcrot D, Wang FY, Jones S, Shulok J, et al. (2002) Small-molecule modulators of Hedgehog signaling: identification and characterization of Smoothened agonists and antagonists. J Biol 1(2): 10 .

54. Cooper MK, Wassif CA, Krakowiak PA, Taipale J, Gong R, Kelley RI, Porter FD, Beachy PA (2003) A defective response to Hedgehog signaling in disorders of cholesterol biosynthesis. Nat Genet 33(4):508-513.

55. Cohen MM Jr (2010) Hedgehog signaling update. Am J Med Genet A 152A(8):1875-1914.

56. Chen Y, Sasai N, Ma G, Yue T, Jia J, Briscoe J, Jiang J (2011) Sonic Hedgehog dependent phosphorylation by CK1 $\alpha$ and GRK2 is required for ciliary accumulation and activation of smoothened. PLoS Biol 9(6):e1001083.

57. Ingham PW, Nakano Y, Seger C (2011) Mechanisms and functions of Hedgehog signalling across the metazoa. Nature Rev Genet 12:393-406.

58. Jacob J, Briscoe J (2003) Gli proteins and the control of spinal-cord patterning. EMBO Rep 4(8):761-765.

59. Ruiz i Altaba A, Mas C, Stecca B (2007) The Gli code: an information nexus regulating cell fate, stemness and cancer. Trends Cell Biol 17(9):438-447.

60. Merchant M, Vajdos FF, Ultsch M, Maun HR, Wendt U, Cannon J, Desmarais W, Lazarus RA, de Vos AM, de Sauvage FJ (2004) Suppressor of fused regulates Gli activity through a dual binding mechanism. Mol Cell Biol 24(19):8627-8641.

61. Svärd J, Heby-Henricson K, Persson-Lek M, Rozell B, Lauth M, Bergström A, Ericson J, Toftgård R, Teglund S (2006) Genetic elimination of Suppressor of fused reveals an essential repressor function in the mammalian Hedgehog signaling pathway. Dev Cell 10(2):187-197.

62. Chen MH, Gao N, Kawakami T, Chuang PT (2005) Mice deficient in the fused homolog do not exhibit phenotypes indicative of perturbed hedgehog signaling during embryonic development. Mol Cell Biol 25(16):7042-7053.

63. Merchant M, Evangelista M, Luoh SM, Frantz GD, Chalasani S, Carano RA, van Hoy M, Raminez J, Ogasawara AK, McFarland LM, et al. (2005) Loss of the serine/threonine kinase fused results in postnatal growth defects and lethality due to progressive hydrocephalus. Mol Cell Biol 25(16):7054-7068.

64. Wang B, Fallon JF, Beachy PA (2000) Hedgehog-regulated processing of Gli3 produces an anterior/posterior repressor gradient in the developing vertebrate limb. Cell 100(4):423-434.

65. Pan Y, Bai CB, Joyner AL, Wang B (2006) Sonic hedgehog signaling regulates Gli2 transcriptional activity by suppressing its processing and degradation. Mol Cell Biol 26(9):3365-3377.

66. Zhang Q, Zhang L, Wang B, Ou CY, Chien CT, Jiang J (2006) A hedgehog-induced BTB protein modulates hedgehog signaling by degrading $\mathrm{Ci} /$ Gli transcription factor. Dev Cell 10(6):719-729.

67. Pan Y, Wang B (2007) A novel protein-processing domain in Gli2 and Gli3 differentially blocks complete protein degradation by the proteasome. J Biol Chem 282(15):10846-10852.

68. Tukachinsky H, Lopez LV, Salic A (2010) A mechanism for vertebrate Hedgehog signaling: recruitment to cilia and dissociation of SuFu-Gli protein complexes. J Cell Biol 191(2):415428.

69. Kinzler KW, Vogelstein B (1990) The GLI gene encodes a nuclear protein which binds specific sequences in the human genome. Mol Cell Biol 10(2):634-642. 
70. Hallikas O, Palin K, Sinjushina N, Rautiainen R, Partanen J, Ukkonen E, Taipale J (2006) Genome-wide prediction of mammalian enhancers based on analysis of transcription-factor binding affinity. Cell 124(1):47-59.

71. Zhang XM, Lin E, Yang XJ (2000) Sonic hedgehog-mediated ventralization disrupts formation of the midbrain-hindbrain junction in the chick embryo. Dev Neurosci 22(3):207216.

72. Hallonet ME, Teillet MA, Le Douarin NM (1990) A new approach to the development of the cerebellum provided by the quail-chick marker system. Development 108:19-31.

73. Hallonet ME, Le Douarin NM (1993) Tracing neuroepithelial cells of the mesencephalic and metencephalic alar plates during cerebellar ontogeny in quail-chick chimaeras. Eur $\mathbf{J}$ Neurosci 5(9):1145-1155.

74. Hallonet ME, Alvarado-Mallart RM (1997) The chick/quail chimeric system: a model for early cerebellar development. Perspect Dev Neurobiol 5(1).17-31.

75. Broccoli V, Boncinelli E, Wurst W (1999) The caudal limit of Otx2 expression positions the isthmic organizer. Nature 401(6749):164-168.

76. Li JY, Lao Z, Joyner AL (2005) New regulatory interactions and cellular responses in the isthmic organizer region revealed by altering Gbx2 expression. Development 132(8):19711981.

77. Martinez S, Wassef M, Alvarado-Mallart RM (1991) Induction of a mesencephalic phenotype in the 2-day-old chick prosencephalon is preceded by the early expression of the homeobox gene engrailed. Neuron 6:971-981.

78. Martinez S, Crossley PH, Cobos I, Rubenstein JL, Martin GR (1999) FGF8 induces formation of an ectopic isthmic organizer and isthmocerebellar development via a repressive effect on Otx2 expression. Development 126(6):1189-1200.

79. Sotelo C (2004) Cellular and genetic regulation of the development of the cerebellar system. Prog Neurobiol 72:295-339.

80. Fuccillo M, Joyner AL, Fishell G (2006) Morphogen to mitogen: the multiple roles of hedgehog signalling in vertebrate neural development. Nat Rev Neurosci 7(10):772-783.

81. Altman J, Bayer SA (1997) Development of the Cerebellar System: In Relation to its Evolution, Structure, and Functions. New York: CRC Press.

82. Hoshino M, Nakamura S, Mori K, Kawauchi T, Terao M, Nishimura YV, Fukuda A, Fuse T, Matsuo N, Sone M, et al. (2005) 'Ptfla, a bHLH transcriptional gene, defines GABAergic neuronal fates in cerebellum. Neuron 47:201-213.

83. Akazawa C, Ishibashi M, Shimizu C, Nakanishi S, Kageyama R (1995) A mammalian helixloop- helix factor structurally related to the product of Drosophila proneural gene atonal is a positive transcriptional regulator expressed in the developing nervous system. $\mathrm{J}$ Biol Chem 270:8730-8738.

84. Seto Y, Nakatani T, Masuyama N, Taya S, Kumai M, Minaki Y, Hamaguchi A, Inoue YU, Inoue T, Miyashita S, et al. (2014) Temporal identity transition from Purkinje cell progenitors to GABAergic interneuron progenitors in the cerebellum. Nat Commun 5:3337.

85. Yamada M, Seto Y, Taya S, Owa T, Inoue YU, Inoue T, Kawaguchi Y, Nabeshima Y, Hoshino M (2014) Specification of spatial identities of cerebellar neuronal progenitors by Ptf1a and Atoh1 for proper production of GABAergic and glutamatergic neurons. $J$ Neurosci 34:4786-4800.

86. Alder J, Cho NK, Hatten ME (1996) Embryonic precursor cells from the rhombic lip are specified to a cerebellar granule neuron identity. Neuron 17:389-399.

87. Wingate RJT (2001) The rhombic lip and early cerebellar development. Curr Opin Neurobiol 11: 82-88. 
88. Machold R, Fishell G (2005) Math1 is expressed in temporally discrete pools of cerebellar rhombic-lip neural progenitors. Neuron 48:17-24.

89. Wang VY, Rose MF, Zoghbi H (2005) Math1 expression redefines the rhombic lip derivatives and reveals novel lineages within the brainstem and cerebellum. Neuron 48:3143.

90. Fink AJ, Englund C, Daza RA, Pham D, Lau C, Nivison M, Kowalczyk T, Hevner RF (2006) Development of the deep cerebellar nuclei: transcription factors and cell migration from the rhombic lip. J Neurosci 26:3066-3076.

91. Englund C, Kowalczyk T, Daza RA, Dagan A, Lau C, Rose MF, Hevner RF (2006) Unipolar brush cells of the cerebellum are produced in the rhombic lip and migrate through developing white matter. J Neurosci 26:9184-9195.

92. Carletti B, Rossi F (2008) Neurogenesis in the cerebellum. The Neuroscientist 14:91-100.

93. Miale IL, Sidman RL (1961) An autoradiographic analysis of histogenesis in the mouse cerebellum. Exp Neurol 4:277-296.

94. Sekerkovà, G., Ilijic, E. and Mugnaini, E. (2004b). Time of origin of unipolar brush cells in the rat cerebellum as observed by prenatal bromodeoxyuridine labeling. Neuroscience. 127:845-858.

95. Dahmane N, Ruiz i Altaba A (1999) Sonic hedgehog regulates the growth and patterning of the cerebellum. Development 126:3089-3100.

96. Corrales JD, Rocco GL, Blaess S, Guo Q, Joyner AL (2004) Spatial pattern of sonic hedgehog signaling through Gli genes during cerebellum development. Development 131:5581-5590.

97. Lewis PM, Gritli-Linde A, Smeyne R, Kottmann A, McMahon AP (2004) Sonic hedgehog signaling is required for expansion of granule neuron precursors and patterning of the mouse cerebellum. Dev Biol 270:393-410.

98. Huang X, Liu J, Ketova T, Fleming JT, Grover VK, Cooper MK, Litingtung Y, Chiang C (2010) Transventricular delivery of Sonic hedgehog is essential to cerebellar ventricular zone development. Proc Natl Acad Sci USA 107:8422-8427.

99. Fujita S, Simada M, Nakanuna T (1966) 3H-thymidine autoradiographic studies on the cell proliferation and differentiation in the external and internal granular layers of the mouse cerebellum. J Comp Neurol 128:191-209.

100. Sidman RL, Lane PW, Dickie MM (1962) Staggerer, a new mutation in the mouse affecting the cerebellum. Science 137(3530):610-612.

101. Rakic P, Sidman RL (1973) Organization of cerebellar cortex secondary to deficit of granule cells in weaver mutant mice. J Comp Neurol 152(2):133-161.

102. Herrup K, Mullen RJ (1979) Staggerer chimeras: intrinsic nature of Purkinje cell defects and implications for normal cerebellar development. Brain Res 178(2-3):443-457.

103. Doughty ML, Delhaye-Bouchaud N, Mariani J (1998) Quantitative analysis of cerebellar lobulation in normal and agranular rats. J. Comp. Neurol 399:306-320.

104. Corrales JD, Blaess S, Mahoney EM, Joyner AL (2006) The level of sonic hedgehog signaling regulates the complexity of cerebellar foliation. Development 133:1811-1821.

105. Behesti H, Marino S (2009) Cerebellar granule cells: insights into proliferation, differentiation, and role in medulloblastoma pathogenesis. Int $\mathrm{J}$ Biochem Cell Biol 41(3):435-445.

106. Roussel MF, Hatten ME (2011) Cerebellum development and medulloblastoma. Curr Top Dev Biol 94:235-282.

107. Choi Y, Borghesani PR, Chan JA, Segal RA (2005) Migration from a mitogenic niche promotes cell-cycle exit. J Neurosci 25(45):10437-10445. 
Ishizaki Y (2006) Control of proliferation and differentiation of neural precursor cells: focusing on the developing cerebellum. J Pharmacol Sci 101(3):183-188.

109. Sonmez E, Herrup K (1984) Role of staggerer gene in determining cell number in cerebellar cortex. II. Granule cell death and persistence of the external granule cell layer in young mouse chimeras. Brain Res 314(2):271-283.

110. Vogel MW, Sunter K, Herrup K (1989) Numerical matching between granule and Purkinje cells in lurcher chimeric mice: a hypothesis for the thropic rescue of granule cells from target-related cell death. J Neurosci 9(10):3454-3462.

111. Smeyne RJ, Chu T, Lewin A, Bian F, S-Crisman S, Kunsch C, Lira SA, Oberdick J, (1995) Local control of granule cell generation by cerebellar Purkinje cells. Mol. Cell. Neurosci 6:230-251.

112. Mullen RJ, Eicher EM, Sidman RL (1976) Purkinje cell degeneration, a new neurological mutation in the mouse. Proc Natl Acad Sci U S A 73(1):208-212.

113. Wallace VA (1999) Purkinje-cell-derived Sonic hedgehog regulates granule neuron precursor cell proliferation in the developing mouse cerebellum. Curr Biol 9:445-448.

114. Wechsler-Reya RJ, Scott MP (1999) Control of neuronal precursor proliferation in the cerebellum by Sonic Hedgehog. Neuron 22:103-114.

115. Nicot A, Lelièvre V, Tam J, Waschek JA, DiCicco-Bloom E (2002) Pituitary adenylate cyclase-activating polypeptide and sonic hedgehog interact to control cerebellar granule precursor cell proliferation. J Neurosci 22(21):9244-9254.

116. Oliver TG, Grasfeder LL, Carroll AL, Kaiser C, Gillingham CL, Lin SM, Wickramasinghe R, Scott MP, Wechsler-Reya RJ (2003) Transcriptional profiling of the Sonic hedgehog response: a critical role for N-myc in proliferation of neuronal precursors. Proc Natl Acad Sci USA 100(12):7331-7336.

117. Knoepfler PS, Cheng PF, Eisenman RN (2002) N-myc is essential during neurogenesis for the rapid expansion of progenitor cell populations and the inhibition of neuronal differentiation. Genes Dev 16(20):2699-2712.

118. Kenney AM, Cole MD, Rowitch DH (2003) Nmyc upregulation by sonic hedgehog signaling promotes proliferation in developing cerebellar granule neuron precursors. Development 130:15-28.

119. Shambaugh GE $3^{\text {rd }}$, Lee RJ, Watanabe G, Erfurth F, Karnezis AN, Koch AE, Haines GK $3^{\text {rd }}$, Halloran M, Brody BA, Pestell RG (1996) Reduced cyclin D1 expression in the cerebella of nutritionally deprived rats correlates with developmental delay and decreased cellular DNA synthesis. J Neuropathol Exp Neurol 55(9):1009-1020.

120. Watanabe G, Pena P, Shambaugh GE $3^{\text {rd }}$, Haines GK $3^{\text {rd }}$, Pestell RG (1998) Regulation of cyclin dependent kinase inhibitor proteins during neonatal cerebella development. Brain Res Dev Brain Res 108(1-2):77-87.

121. Parmigiani E, Leto K, Rolando C, Figueres-Onãte M, López-Mascaraque L, Buffo A, Rossi F (2015) Heterogeneity and Bipotency of Astroglial-Like Cerebellar Progenitors along the Interneuron and Glial Lineages. J Neurosci 35(19):7388-7402.

122. Durand B, Fero ML, Roberts JM, Raff MC (1998) p27Kip1 alters the response of cells to mitogen and is part of a cell-intrinsic timer that arrests the cell cycle and initiates differentiation. Curr Biol 8(8):431-440.

123. Miyazawa K, Himi T, Garcia V, Yamagishi H, Sato S, Ishizaki Y (2000) A role for p27/Kip1 in the control of cerebellar granule cell precursor proliferation. J Neurosci 20(15):5756-5763.

124. Pons S, Trejo JL, Martinez-Morales JR, Marti E (2001) Vitronectin regulates Sonic hedgehog activity during cerebellum development through CREB phosphorylation. Development 128(9):1481-1492. 
125. Weisheit G, Gliem M, Endl E, Pfeffer PL, Busslinger M, Schilling K (2006) Postnatal development of the murine cerebellar cortex: formation and early dispersal of basket, stellate and Golgi neurons. Eur J Neurosci 24:466-478.

126. Maricich SM, Herrup K (1999) Pax-2 expression defines a subset of GABAergic interneurons and their precursors in the developing murine cerebellum. J Neurobiol 41:281294.

127. Zhang L, Goldman JE (1996) Generation of cerebellar interneurons from dividing progenitors in white matter. Neuron 16(1):47-54.

128. Leto K, Carletti B, Williams IM, Magrassi L, Rossi F (2006) Different types of cerebellar GABAergic interneurons originate from a common pool of multipotent progenitor cells. J Neurosci 26:11682-11694.

129. Leto K, Bartolini A, Yanagawa Y, Obata K, Magrassi L, Schilling K, Rossi F (2009) Laminar fate and phenotype specification of cerebellar GABAergic interneurons. J Neurosci 29:7079-7091.

130. Sudarov A, Turnbull RK, Kim EJ, Lebel-Potter M, Guillemot F, Joyner AL (2011) Ascl1 genetics reveals insights into cerebellum local circuit assembly. J Neurosci 31:1105511069.

131. Klein C, Butt SJ, Machold RP, Johnson JE, Fishell G (2005) Cerebellum- and forebrain-derived stem cells possess intrinsic regional character. Development 132:44974508.

132. Lee A, Kessler JD, Read TA, Kaiser C, Corbeil D, Huttner WB, Johnson JE, Wechsler-Reya RJ (2005) Isolation of neural stem cells from the postnatal cerebellum. Nat Neurosci 6:723-729.

133. Milosevic A, Goldman JE (2004) Potential of progenitors from postnatal cerebellar neuroepithelium and white matter: lineage specified vs. multipotent fate. Mol Cell Neurosci 26(2):342-353.

134. Grimaldi P, Parras C, Guillemot F, Rossi F, Wassef M (2009) Origins and control of the differentiation of inhibitory interneurons and glia in the cerebellum. Dev. Biol 328:422433.

135. Silbereis J, Cheng E, Ganat YM, Ment LR, Vaccarino FM (2009) Precursors with glial fibrillary acidic protein promoter activity transiently generate GABA interneurons in the postnatal cerebellum. Stem Cells 27:1152-1163.

136. Fleming JT, He W, Hao C, Ketova T, Pan FC, Wright CV, Litingtung Y, Chiang C (2013) The Purkinje neuron acts as a central regulator of spatially and functionally distinct cerebellar precursors. Dev Cell 27:278-292.

137. De Luca A, Parmigiani E, Tosatto G, Martire S, Hoshino M, Buffo A, Leto K, Rossi F (2015) Exogenous sonic hedgehog modulates the pool of GABAergic interneurons during cerebellar development. Cerebellum. 14:72-85.

138. Schilling K, Oberdick J, Rossi F, Baader SL (2008) Besides Purkinje cells and granule neurons: an appraisal of the cell biology of the interneurons of the cerebellar cortex. Histochem Cell Biol 130:601-615.

139. Ramón y Cajal S (1911) Histologie du système nerveux de l'homme et des vertébrés. Paris: Maloine.

140. Palay S, Chan-Palay V (1974) Cerebellar Cortex. Springer-Verlag, Berlin, Heidelberg, New York.

141. Buffo A, Rossi F (2013) Origin, lineage and function of cerebellar glia. Prog Neurobiol 109:42-63.

142. Yuasa S (1996) Bergmann glial development in the mouse cerebellum as revealed by tenascin expression. Anat Embryol 194:223-234. 
143. Yamada K, Watanabe M (2002) Cytodifferentiation of Bergmann glia and its relationship with Purkinje cells. Anat Sci Int 77:94-108.

144. Mori T, Tanaka K, Buffo A, Wurst W, Kuehn R, Goetz M (2006) Inducible gene deletion in astroglia and radial glia - a valuable tool for functional and lineage analysis. Glia. 54:21-34.

145. Sotelo C, Alvarado-Mallart RM (1991) The reconstruction of cerebellar circuits. Trends Neurosci 14(8):350-355.

146. Rossi F, Borsello T, Strata P (1992) Embryonic Purkinje Cells Grafted on the Surface of the Cerebellar Cortex Integrate in the Adult Unlesioned Cerebellum. Eur J Neurosci 4(6):589-593.

147. Wallace VA, Raff MC (1999) A role for Sonic hedgehog in axon-to-astrocyte signalling in the rodent optic nerve. Development 126(13):2901-2909.

148. Sehgal R, Sheibani N, Rhodes SJ, Belecky Adams TL (2009) BMP7 and SHH regulate Pax2 in mouse retinal astrocytes by relieving TLX repression. Dev Biol 332(2):429-443.

149. Garcia AD, Petrova R, Eng L, Joyner AL (2010) Sonic hedgehog regulates discrete populations of astrocytes in the adult mouse forebrain. J Neurosci 30(41):13597-13608.

150. Poncet C, Soula C, Trousse F, Kan P, Hirsinger E, Pourquié O, Duprat AM, Cochard A (1996) Induction of oligodendrocyte progenitors in the trunk neural tube by ventralizing signals: effects of notochord and floor plate grafts, and of sonic hedgehog. Mech Dev 60(1):13-32.

151. Lu QR, Yuk D, Alberta JA, Zhu Z, Pawlitzky I, Chan J, McMahon AP, Stiles CD, Rowitch DH (2000) Sonic hedgehog-regulated oligodendrocyte lineage genes encoding bHLH proteins in the mammalian central nervous system. Neuron 25:317-329.

152. Lu Q, Sun T, Zhu Z, Ma N, Garcia M, Stiles CD, Rowitch DH (2002) Common developmental requirement for Olig function indicates a motor neuron/oligodendrocyte connection. Cell 109:75-86.

153. Alberta JA, Park SK, Mora J, Yuk D, Pawlitzky I, Iannarelli P, Vartanian T, Stiles CD, Rowitch DH (2001) Sonic hedgehog is required during an early phase of oligodendrocyte development in mammalian brain. Mol Cell Neurosci 18(4):434-441.

154. Danesin C, Agius E, Escales N, Ai X, Emerson C, Cochard P, Soula C (2006) Ventral neural progenitors switch toward an oligodendroglial fate in response to increased Sonic hedgehog (Shh) activity: involvement of Sulfatase 1 in modulating Shh signaling in the ventral spinal cord. J Neurosci 26(19):5037-5048.

155. Merchán P, Bribián A, Sánchez-Camacho C, Lezameta M, Bovolenta P, de Castro F (2007) Sonic hedgehog promotes the migration and proliferation of optic nerve oligodendrocyte precursors. Mol Cell Neurosci 36(3):355-368.

156. Ortega MC, Cases O, Merchán P, Kozyraki R, Clemente D, de Castro F (2012) Megalin mediates the influence of sonic hedgehog on oligodendrocyte precursor cell migration and proliferation during development. Glia 60(6):851-866.

157. Traiffort E, Charytoniuk DA, Faure H, Ruat M (1998) Regional distribution of Sonic Hedgehog, patched, and smoothened mRNA in the adult rat brain. J Neurochem 70(3):132730.

158. Fisher M, Trimmer P, Ruthel G (1993) Bergmann glia require continuous association with Purkinje cells for normal phenotype expression. Glia 8(3):172-182.

159. Mecklenburg N, Martinez-Lopez JE, Moreno-Bravo JA, Perez-Balaguer A, Puelles E, Martinez S (2014) Growth and differentiation factor 10 (Gdf10) is involved in Bergmann glial cell development under Shh regulation. Glia 62(10):1713-1723. 
160. Bouslama-Oueghlani L, Wehrlé R, Doulazmi M, Chen XR, Jaudon F, LemaigreDubreuil Y, Rivals I, Sotelo C, Dusart I (2012) Purkinje cell maturation participates in the control of oligodendrocyte differentiation: role of Sonic hedgehog and vitronectin. PLoS One 7(11):e49015.

161. Barres, B. A. and Raff, M. C. (1993). Proliferation of oligodendrocyte precursor cells depends on electrical activity in axons. Nature. 361(6409):258-260.

162. Trapp BD, Nishiyama A, Cheng D, Macklin W (1997) Differentiation and death of premyelinating oligodendrocytes in developing rodent brain. J Cell Biol 137(2):459-468.

163. Burne JF, Staple JK, Raff MC (1996) Glial cells are increased proportionally in transgenic optic nerves with increased numbers of axons. J Neurosci 16(6):2064-2073.

164. Sudarov A, Joyner AL (2007) Cerebellum morphogenesis: the foliation pattern is orchestrated by multi-cellular anchoring centers. Neural Dev 3:26.

165. Kool M, Koster J, Bunt J, Hasselt NE, Lakeman A, van Sluis P, Troost D, Meeteren NS, Caron HN, Cloos J, et al. (2008) Integrated genomics identifies five medulloblastoma subtypes with distinct genetic profiles, pathway signatures and clinicopathological features. PLoS One 3:e3088.

166. Northcott PA, Korshunov A, Witt H, Hielscher T, Eberhart CG, Mack S, Bouffet E, Clifford SC, Hawkins CE, French P, et al. (2011) Medulloblastoma comprises four distinct molecular variants. J Clin Oncol 29:1408-1414.

167. Northcott PA, Hielscher T, Dubuc A, Mack S, Shih D, Remke M, Al-Halabi H, Albrecht S, Jabado N, Eberhart CG, et al. (2011) Pediatric and adult sonic hedgehog medulloblastomas are clinically and molecularly distinct. Acta Neuropath 122:231-240.

168. Northcott PA, Shih DJ, Peacock J, Garzia L, Morrissy AS, Zichner T, Stütz AM, Korshunov A, Reimand J, Schumacher SE, et al. (2012) Subgroup-specific structural variation across 1,000 medulloblastoma genomes. Nature 488:49-56.

169. Aref D, Moffatt CJ, Agnihotri S, Ramaswamy V, Dubuc AM, Northcott PA, Taylor MD, Perry A, Olson JM, Eberhart CG, et al. (2012) Canonical TGF-beta pathway activity is a predictor of SHH-driven medulloblastoma survival and delineates putative precursors in cerebellar development. Brain Pathol 23(2):178-191.

170. Oliver TG, Read TA, Kessler JD, Mehmeti A, Wells JF, Huynh TT, Lin SM, Wechsler-Reya RJ (2005) Loss of patched and disruption of granule cell development in a pre-neoplastic stage of medulloblastoma. Development 132:2425-2439.

171. Crawford JR, MacDonald TJ, Packer RJ (2007) Medulloblastoma in childhood: new biological advances. Lancet Neurol 6:1073-1085.

172. Raffel C (2004) Medulloblastoma: molecular genetics and animal models. Neoplasia 6:310-322.

173. Taylor MD, Liu L, Raffel C, Hui CC, Mainprize TG, Zhang X, Agatep R, Chiapa S, Gao L, Lowrance A, et al. (2002) Mutations in SUFU predispose to medulloblastoma. Nat Genet. 31:306-310.

174. Taylor MD, Northcott PA, Korshunov A, Remke M, Cho YJ, Clifford SC, Eberhart CG, Parsons DW, Rutkowski S, Gajjar A, et al. (2012) Molecular subgroups of medulloblastoma: the current consensus. Acta Neuropathol 123:465-72.

175. Eberhart CG (2003) Medulloblastoma in Mice Lacking p53 and PARP. All Roads Lead To Gli. Am J Pathol 162(1):7-10.

176. Hatton BA, Villavicencio EH, Tsuchiya KD, Pritchard JI, Ditzler S, Pullar B, Hansen S, Knoblaugh SE, Lee D, Eberhart CG, et al. (2008) The Smo/Smo model: hedgehoginduced medulloblastoma with $90 \%$ incidence and leptomeningeal spread. Cancer Res 68(6):1768-1776. 
177. Goodrich, L. V., Milenkovic, L., Higgins, K. M. and Scott, M. P. (1997). Altered neural cell fates and medulloblastoma in mouse patched mutants. Science. 277:1109-1113.

178. Goodrich LV, Scott MP (1998) Hedgehog and patched in neural development and disease. Neuron 21:1243-1257.

179. Gorlin RJ (1995) Nevoid basal cell carcinoma syndrome. Dermatol Clin 13:113-125.

180. Kim J, Nelson AL, Algon SA, Graves O, Sturla LM, Goumnerova LC, Rowitch DH, Segal RA, Pomeroy SL (2003) Medulloblastoma tumorigenesis diverges from cerebellar granule cell differentiation in patched heterozygous mice. Dev Biol 263:50-66.

181. Brugières L, Remenieras A, Pierron G, Varlet P, Forget S, Byrde V, Bombled J, Puget S, Caron O, Dufour C, et al. (2012) High frequency of germline SUFU mutations in children with desmoplastic/nodular medulloblastoma younger than 3 years of age. J Clin Oncol 30:2087-2093.

182. Smith MJ, Beetz C, Williams SG, Bhaskar SS, O’Sullivan J, Anderson B, Daly SB, Urquhart JE, Bholah Z, Oudit D, et al. (2014) Germline Mutations in SUFU Cause Gorlin Syndrome- Associated Childhood Medulloblastoma and Redefine the Risk Associated With PTCH1 Mutations. J Clin Oncol 32(36):4155-4161.

183. Yoon JW, Gilbertson R, Iannaccone S, Iannaccone P, Walterhouse D (2008) Defining a role for Sonic hedgehog pathway activation in desmoplastic medulloblastoma by identifying GLI1 target genes. Int J Cancer 124:109-119.

184. Buczkowicz P, Ma J, Hawkins C (2011) GLI2 is a potential therapeutic target in pediatric medulloblastoma, J Neuropathol Exp Neurol 70(6):430-437.

185. Li P, Du F, Yuelling LW, Lin T, Muradimova RE, Tricarico R, Wang J, Enikolopov G, Bellacosa A, Whechsler-Reya RJ et al. (2013) A population of Nestin-expressing progenitors in the cerebellum exhibiths increased tumorigenicity. Nat Neurosci. 16(12):1737-1744.

186. Park M, Park HJ, Eom HS, Kwon YJ, Park JA, Lim YJ, Yoon JH, Kong SY, Ghim TT, Lee HW, et al. (2013) Safety and effcts of prophylactic defibrotide for sinusoidal obstruction syndrome in hematopoietic stem cell transplantation. Ann Transplant 18:36-42.

\section{Figure legends.}

Figure 1. Shh signalling pathway in Vertebrates. (A1) Shh protein is synthesized as $45 \mathrm{kDa}$ precursor protein (Shh) that is palmitoylated at the N-terminus and concomitantly auto-catalytically cleaved. Successively, a cholesterol-modification occurs to obtain a $19 \mathrm{kDa}$ dually lipidated Nterminal signaling protein (SHH-N). Shh is then trafficked to the cell surface and released from cells as a multimer (M-Shh-N) in a process mediated by Dispatched1 (Disp1). (A2) Interactions with both megalin and glypicans regulate the long range Shh signalling. Binding to the transmembrane protein megalin promotes Shh internalization, resulting in either degradation or subsequent exocitosis. The Shh affinity for megalin is increased by glypicans. (B 1 ) Primary cilia are key organelles where Shh signalling takes place. On their membranes both receptors (ptch1) and coreceptors $(\mathrm{Cdo} / \mathrm{Boc})$ are exposed. These structures also contain regulatory microtubule-associated 
complexes composed by Suppressor of Fused (Sufu), Kif7, PKA, GSK3, CK1 and Gli proteins. In the absence of Shh, Ptch1 prevents membrane localization and activation of Smo, retaining it on intracellular vesicles. In this context, Gli proteins are held in the microtubule-associated complex, that induces Gli protein phosphorylation ( $\mathbf{r e d} \mathbf{P})$ to obtain a transcriptional repressor form (Gli repressor). ( $\left.\mathbf{B}_{2}\right)$ When Shh interacts with the Ptch1 and Cdo/Boc, Smo is shuttled from an endocytic vesicle to the cilium whereas hedgehog patched complex is internalized and degraded by lysosomes. (B3) The de-repression of Smo induces the dissociation of Sufu-Gli-kinases complex promoting formation of the Gli activator form (Gli activator), that after nuclear translocation activates transcription of downstream targets.

Figure 2. Shh functions during cerebellar development.

(A) During the embryonic development, Shh is first secreted by choroid plexi (ChP) and is essential to radial glial cell proliferation and expansion of $\mathrm{Ptfla}^{+}$progenitors of GABAergic neurons. Purkinje cells start the secretion of this morphogen by E17.5, modulating the correct differentiation of glial progenitors into mature BG. (B) Postnatally, Shh acts as a mitogen on both granule and oligodendrocyte precursor cells (GCPs and OPCs), in the EGL and PWM respectively. In the PWM, Shh also exerts a proliferative function on the neural stem-cell-like progenitors $\left(\mathrm{Tnc}^{+} \mathrm{CD} 133^{+}\right)$that generate both intermediate astrocyte precursors $\left(\mathrm{Tnc}^{+} \mathrm{CD} 15^{+}\right)$and GABAergic transient amplifying cells $\left(\mathrm{Ptfla}^{+}\right)$. PWM, prospective white matter; IGL, internal granular layer; PCL, Purkinje cell layer; EGL, external granular layer 


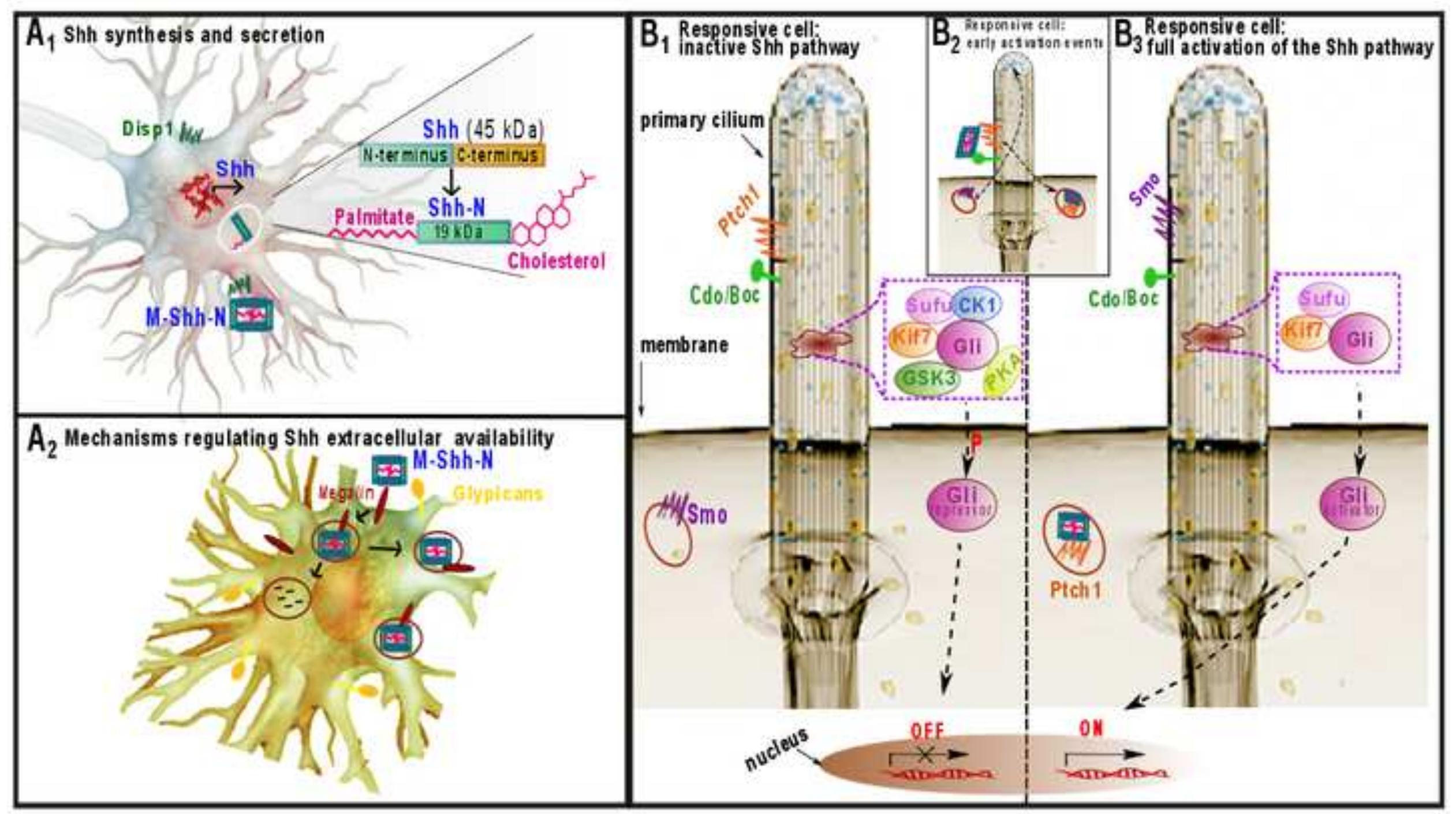




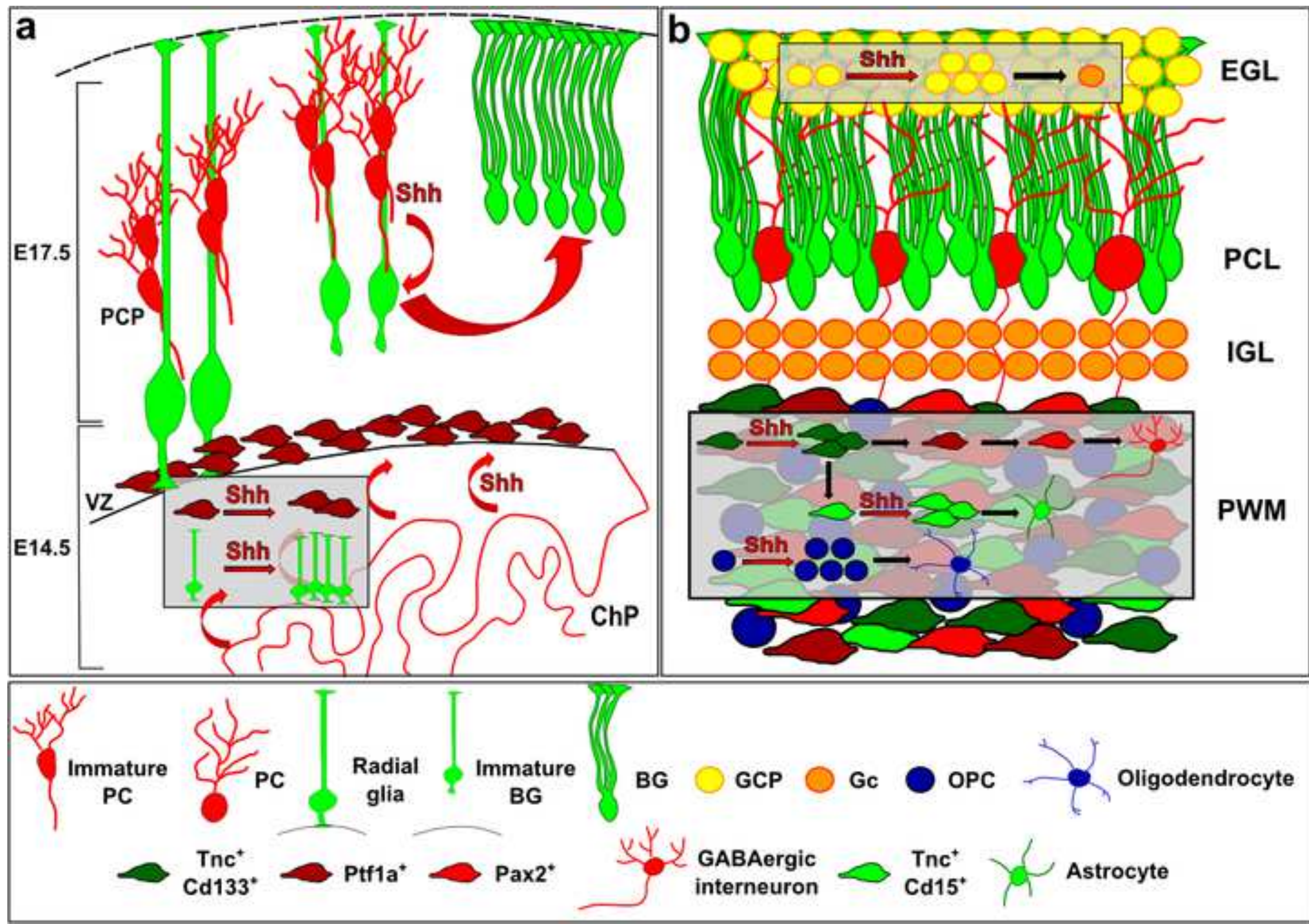




\section{IIIS AperTO}

UNIVERSITÀ

DEGLI STUDI

DI TORINO

This is the author's final version of the contribution published as:

Sonic hedgehog patterning during cerebellar development.

De Luca A, Cerrato V, Fucà E, Parmigiani E, Buffo A, Leto K.

Cell Mol Life Sci. 2016 Jan;73(2):291-303. doi: 10.1007/s00018-015-2065-1.

The publisher's version is available at:

http://link.springer.com/article/10.1007\%2Fs00018-015-2065-1

When citing, please refer to the published version.

Link to this full text:

http://link.springer.com/article/10.1007\%2Fs00018-015-2065-1 